\title{
"STATE ACTION" AND THE GIRARD ESTATE CASE
}

\section{Hershel Shanks $\dagger$}

Stephen Girard ${ }^{1}$ was a man of grand conception. But even his spacious imagination could not have envisaged the impact his carefullydrawn $^{2}$ will was to have on the legal world. Dead these 125 years, Girard has attained immortality in the law for the legal controversies engendered by the famous will. Without challenge, the thirty-two page document lays claim to the title of the most litigated will in history. Twice has its validity been debated in the highest court of the land; ${ }^{3}$ hydraheaded, it has been to the Supreme Court of Pennsylvania at least ten times; ${ }^{4}$ its appearances before inferior courts are without number.

Its finest performance to date was in the landmark case of Vidal $v$. Mayor, ${ }^{5}$ which brought into the fray on opposing sides the two gargantuan advocates of their day, Horace Binney and Daniel Webster. The result was an opinion which established the validity of the charitable trust in the United States and has become the bedrock of American charitable trust law. ${ }^{\circ}$ Having put the law of charitable trusts on a firm basis, Stephen Girard's will now turns to more fashionable matter,

† Member, District of Columbia Bar. A.B., 1952, Haverford College; A.M., 1953, Columbia University; LL.B., 1956, Harvard University.

1. 1750-1831. Biographies of this fascinating early American figure include Wildes, LONELY MIDAs (1943) and Hierrick, StepHeN GrRard, Founder (1923).

2. William J. Duane, the scrivener of the final Girard will, testified before a Select Committee of the Pennsylvania House of Representatives on the Estate of Stephen Girard in 1842 as to the method of drawing the will. Duane's testimony is summarized in id. at 143: ". . . Duane stated that he remained with Girard five or six weeks with the doors locked, and that in connection with this service all sorts of topics were discussed by Girard and Duane, including law, politics, religion, and architecture. The writing was gone over two or three times and drafts of the several sections were made. Duane further describes the procedure in a statement that a draft, when submitted to Girard, would be altered and remodeled in accordance with his own ideas, and that, after such revision, the section would be written over in its final form. Duane paid Girard a great compliment by declaring that he was 'a good judge of languagenone better.' Of his part in writing the Will, Duane added that he 'took the most anxious pains to do in writing, what Mr. Girard would, if he had been a painter, have exhibited on the canvas." "

3. Vidal v. Mayor, 43 U.S. (2 How.) 126 (1844) ; Girard v. Philadelphia, 74 U.S. (7 Wall.) 1 (1868).

4. In addition to the two cases cited in note 3 supra: Girard v. Mayor, 4 Rawle 323 ( $\mathrm{Pa}$. 1833) ; Beck v. Philadelphia, $17 \mathrm{~Pa} 104$ (1851); Soohan v. Philadelphia, 33 Pa. 9 (1859); Philadelphia v. Heirs of Girard, 45 Pa. 9 (1863); Field v. Directors of Girard College, $54 \mathrm{~Pa} .233$ (1867); Philadelphia v. Fox, $64 \mathrm{~Pa}$. 169 (1870); Girard's Appeal, 4 Penny. 347 (Pa. 1880) ; In Re Estate of Stephen Girard, 127 A.2d 287 ( $\mathrm{Pa}$. 1956).

5. 43 U.S. (2 How.) 126 (1844).

6. See 4 Scotr, TRUSTS $\$ \S 348,348.3$ (2d ed. 1956). 
constitutional law. In the tumultuous world of constitutional law, it has already created its own furor. The result may be as far-reaching as the Vidal case, for the present Girard Estate case ${ }^{7}$ offers an opportunity to consolidate a decade of decisions and thinking on "state action." This, then, is the raison d'etre of the present discussion.

The heart of Girard's testamentary plan of disposition-as today's estate planners would call it-was the establishment of a "College" into which were to be admitted "as many poor white male orphans between the ages of six and ten years, as the said income shall be adequate to maintain. . . ." 8 The college was to be established and maintained by the "'Mayor, Aldermen and Citizens of Philadelphia' ${ }^{8}$ their successors and assigns" 10 as trustee.

Girard College- the name was neither Girard's suggestion nor command-has since its founder's death become the world's largest boarding school, housing, educating and caring for over 1,100 fatherless boys. The original endowment of $\$ 2,000,000$ has grown to $\$ 97,000,000$. The envy of many private as well as public schools, Girard College spends between $\$ 15,000$ and $\$ 20,000$ on each student during his stay. In accordance with the will's instructions the boys enter between the ages of six and ten, and leave between the ages of fourteen and eighteen, usually the latter. In addition to the usual educational curriculum, students are taught ten trades from auto mechanic to draftsman, one of which is learned more thoroughly. Thus is fulfilled Girard's request that, they be "taught facts and things, rather than words and signs. . . ." 11 Many of the boys go on to college, and of these a large portion become honor students.

7. In re Estate of Stephen Girard, 127 A.2d 287 (Pa. 1956), affirming 4 D. \& C.2d 671 (Philadelphia County Orphans Ct. 1956).

8. Girard Will cl. XXI.

9. This designation of the municipal corporation was changed by the Act of Feb. 2, 1854, PA. Srat. ANN. tit. 53, § 6361 (Purdon 1931), to "The City of Philadelphia."

10. Girard Will cl. XX.

11. Id. cl. XXI. One of the most widespread misconceptions about the school stems largely from Daniel Webster's accusation in the Vidal case that the school was founded for propogating atheism. 43 U.S. (2 How.) at 173. This accusation was based on the will's command that no minister nor ecclesiastic shall enter the College, even as a visitor. Girard's will explained the proscription: ". . I I do not mean to cast any reflection upon any sect or person whatsoever; but, as there is such a multitude of sects, and such a diversity of opinion amongst them, I desire to keep the tender minds of the orphans, who are free to derive advantage from this bequest, free from the excitement which clashing doctrines and sectarian controversy are so apt to produce; my desire is, that all the instructors and the teachers in the college shall take pains to instil into the minds of the scholars the purest principles of morality, so that, on their entrance into active life, they may, from inclination and habit, evince benevolence towards their fellow-creatures, and a love of truth, sobriety, and industry, adopting at the same time such religious tenets as their matured reason may enable them to prefer." Girard Will cl. XXI. The boys receive a thorough religious education based on the Scriptures. In the beautiful college chapel where attendance is compulsory, a nonsectarian book of worship is used. While there is thus a total absence of denominationalism in religious teaching within the wall, the boys are encouraged to follow the religion of their parents and to attend denominational worship outside the school. 
On February 1, 1954 two poor Negro male orphans between the ages of six and ten years applied for admission to Girard College. These applications were rejected solely on the ground that the applicants were not "white" as required by the Girard will.

The rejected Negro applicants sought the aid of the courts in their attempt to be admitted. They claimed that the refusal to admit them solely on the basis of their color was a violation of their constitutional rights in that this discriminatory action was, within the meaning of the fourteenth amendment, ${ }^{12}$ taken by the state and that they were thus deprived of equal protection of the laws. ${ }^{13}$ The Board of Directors of City Trusts, which now serves as agent of the city to administer its fiduciary duties and powers with respect to charitable trusts, ${ }^{14}$ denied a constitutional violation.

The three Pennsylvania courts which have heard the case ${ }^{15}$ have all found in favor of the Board of City Trusts, that Negroes need not be admitted. The Supreme Court of Pennsylvania handed down its decision on November 12, 1956 and produced a lone dissent. ${ }^{16}$ It appears likely that review ${ }^{17}$ will now be sought in the Supreme Court of the United States.

To determine whether municipal management of a charitable trust results in state action within the meaning of the fourteenth amendment,

12. "No State shall make or enforce any law which shall abridge the privileges or immunities of citizens of the United States; nor shall any State deprive any person of life, liberty, or property, without due process of law; nor deny to any person within its jurisdiction the equal protection of the laws." U.S. CoNST. amend. XIV, § 1 .

13. The petitioners' briefs argued several non-constitutional grounds for a decision in their favor: (1) Violation of the public policy of the city and state governments. (2) The purpose of the trust has already failed in that a proper education in the terms in which Girard defined it cannot be received in a segregated atmosphere. Therefore cy pres should be applied and Negroes admitted in order to accomplish the purpose of the testator. (3) The trust violates this country's obligations under the United Nations Charter. Cf. Sayre, Shelley v. Kraener and United Nations Law, 34 IowA L. REv. 1 (1948).

14. The Board is composed of the Mayor, the President of the Councilmanic Chamber and twelve citizens appointed by the Judges of the Courts of Common Pleas of Philadelphia. An unsuccessful attack on the Girard Trust on the basis of the Board's serving as trustee was made in Philadelphia v. Fox, $64 \mathrm{~Pa} .169$ (1870).

15. The opinions of both the hearing judge and the Orphans' Court en banc may be found in Girard Estate, $4 \mathrm{~Pa}$. D. \& C.2d 671 (Philadelphia County Orphans Ct. 1956). The Supreme Court opinion has been reported officially as In re Estate of Stephen Girard, 127 A.2d 287 (Pa. 1956).

16. Justice Musmanno dissented. Chief Justice Stern wrote for the majority and Justice Bell wrote a concurring opinion. The distributed slip opinions consumed eightytwo pages.

17. There may be an attempt to seek review by appeal rather than certiorari under 28 U.S.C. $\$ 1257(2)$ (1952) based on the fact that several statutes were passed by the Pennsylvania legislature to implement the trust. Section $125 \%$ provides: "Final judgments or decrees rendered by the highest court of a State in which a decision could be had, may be reviewed by the Supreme Court as follows: .... (2) By appeal, where is drawn in question the validity of a statute of any state on the ground of its being repugnant to the Constitution, treaties or laws of the United States, and the decision is in favor of its validity." 
we shall first examine the indistinct guideposts afforded by present Supreme Court literature. Next we shall follow the paths which other state and lower federal courts have cut into the "state action" wilderness. Finally, we shall attempt to extricate from all these cases two relatively general propositions which may provide a satisfactory approach to the Girard Estate case as well as to other "state action" cases which the future promises to provide.

\section{The Supreme Court Cases}

\section{Exclusive State Functions}

Our consideration of Supreme Court cases dealing with "state action" begins midway in the dramatic series of white primary cases in which the Negro legally fought for his right to cast an effective ballot. ${ }^{18}$ In Smith v. Allwright ${ }^{19}$ the Supreme Court for the first time applied constitutional restrictions to a private organization. The Court held that the action of the Democratic Party of Texas, in passing a resolution excluding Negroes from membership, was "state action" and violative of the Constitution.

Until this time the only individual action that had been held subject to constitutional limitations was that encompassed by the phrase "acting under color of law," whereby governmental officers were held to be acting for the state even though they acted outside their authority. ${ }^{20}$ Smith v. Allwright went one step further by applying the fourteenth amendment to a group which technically had no legal connection with the state. When the party acted, the state acted. The party was the agent of the state in spite of the fact that the state only permitted the resolution rather than commanded it. "[T] he recognition of the place of the primary in the electoral scheme makes clear that state delegation to a party of the power to fix the qualifications of primary elections is delegation of a state function that may make the party's action the action of the State." 21

18. Nixon v. Herndon, 273 U.S. 536 (1927) (holding unconstitutional a state law excluding Negroes from voting in primaries) ; Nixon v. Condon, 286 U.S. 73 (1932) (holding unconstitutional a state statute giving the Democratic party's executive committee the power to lay down qualifications for membership); Grovey v. Townsend, 295 U.S. 45 (1935) (holding valid a resolution excluding Negroes adopted by the Texas Democratic Party membership as a whole); Smith v. Allwright, 321 U.S. 649 (1944) (overruling Grovey v. Townsend, supra); Rice v. Elmore, 165 F.2d 387 (4th Cir. 1947), cert. denied, 333 U.S. 875 (1948) (holding primary still subject to constitutional limitations even though it was in no way controlled by state regulation); Terry v. Adams, 345 U.S. 461 (1953). (holding a private organization which held a straw primary prior to the Democratic primary and functioned as part of the electoral process must not discriminate against Negroes).

19. 321 U.S. 649 (1944).

20. E.g., Ex parte Virginia, 100 U.S. 339 (1870).

21. 321 U.S. at 660 . 
The inevitable conclusion followed: "When primaries become a" part of the machinery for choosing officials, state and national, as they have here, the same tests to determine the character of discrimination or abridgement should be applied to the primary as are applied to the general election." ${ }^{22}$ This principle was applied to a slightly varying fact situation by a lower federal court, ${ }^{23}$ and was fortified by a final Supreme Court decision, Terry v. Adams. ${ }^{24}$ The "Jaybird Primary" case, as Terry $v$. Adams is called, held that a half-century old political organization that conducted its own straw primary prior to the statutory primary was nevertheless subject to constitutional limitations in choosing its membership, since it functioned as part of the electoral machinery. A victory in the straw primary was tantamount to a victory in the election. This was enough for the Supreme Court, despite the fact that, as Justice Frankfurter pointed out, "formal state action, either by way of legislative recognition or official authorization, is wholly wanting." 25

These white primary cases arose under the fifteenth amendment ${ }^{26}$ rather than the fourteenth amendment. On this ground the cases might have been restricted, had the Supreme Court chosen to do so, to the right to vote. That the Court did not so choose is clear from its decision in Marsh v. Alabama. ${ }^{27}$

The facts of the Marsh case are simply stated: Chickasaw, Alabama, is a company-owned town. Title to the property is in the Gulf Shipbuilding Corporation. "Except for that it has all the characteristics of any other American town." 28 A Jehovah's Witness undertook to pass out religious literature while standing on the company-owned sidewalk. Upon her refusal to leave, she was arrested pursuant to an Alabama statute which makes it a crime to enter or remain on the premises of another after having been warned not to do so. Her conviction under this statute was reversed by the Supreme Court of the United States. The statute as applied to her was unconstitutional, since it violated her freedom of speech and religion as guaranteed against state abridgement by the fourteenth amendment. By operating a municipality, a private party was held to act for the state.

With prophetic words, Justice Black wrote for the majority: "When we balance the Constitutional rights of owners of property

22. $I d$. at 664 .

23. Rice v. Elmore, 165 F.2d 387 (4th Cir. 1947), cert. denied, 333 U.S. 875(1948).

24. 345 U.S. 461 (1953).

25. Id. at 471 .

26. "The right of citizens of the United States to vote shall not be denied or abridged by the United States or by any State on account of race, color, or previous condition of servitude." U.S. CoNST. amend. XV, § 1 .

27. 326 U.S. 501 (1946).

28. Id. at 502 . 
against those of the people to enjoy freedom of press and religion, as we must here, we remain mindful of the fact that the latter occupy a preferred position." 29

Both the white primary cases and Marsh $v$. Alabama may easily be circumscribed by explaining them in terms of what may be called the state function theory. According to this theory a private individual or group is subject to constitutional limitations when it undertakes to perform a function regarded as the exclusive function of the state. The emphasis is on the word "exclusive." Thus it could be argued that these cases are inapplicable to Girard Estate because, though education is a function of the state, it is not exclusively so.

While it is true that in any case in which the application of the "state function" theory is considered there must of necessity be a proper dual function exercised, the white primary cases and Marsh can still be distinguished from the Girard Estate case by the fact that in the educational sphere there is a legitimate area in which the educational function may be exercised free of constitutional restraints. Every election or operation of a community is subject to constitutional limitations no matter who undertakes to perform the function, but this is not true of every school. Indeed, the Constitution protects the right of a teacher to teach outside the state system of education and the right of a student to attend a school outside the state system, provided the state's minimum educational requirements are met. ${ }^{30}$

On the other hand, these cases may be given a broader reading, treating them as suggestive rather than precedential. They are examples of situations where acts of private individuals and groups are subject to constitutional restraints in spite of the fact that the state simply permitted the act. In Marsh, it should be noted, the state did not even condone the constitutional violation. No state policy to suppress freedom of religion or speech can be implied from the application of the statute to Marsh. Alabama was concerned only with the protection of property rights. Nevertheless state action was present.

The lesson is that under some circumstances when the state permits private individuals or groups to violate rights guaranteed by the Constitution against state infringement, the state is held to approve the action and state action results. The state commands, forbids or permits all action. When it permits action, it has the power-subject always to

29. Id. at 509 .

30. See Pierce v. Society of Sisters, 268 U.S. 510 (1925) ; Bartels v. Iowa, 262 U.S. 404 (1923); Meyer v. State, 262 U.S. 390 (1923) ; Commonweaith v. Beiler, 168 Pa. Super. 462, 464, 79 A.2d 134, 135 (1951) (dictum); Commonwealth ex rel. School District v. Bey, 166 Pa. Super. 136, 138, 70 A.2d 693, 694 (1950) (dictum). 
constitutional limitations-to forbid this action. In some instances, it is unconstitutional for the state to abdicate this power. Justice Frankfurter's words in Terry $v$. Adams are pertinent: "The evil here is that the State, through the actions and the abdication of those whom it has clothed with authority, has permitted white voters to go through a procedure which predetermines the legally devised primary." 31

\section{Judicial Frontiers: Exasperation and Trepidation}

Clearly all behavior which the state permits is not imputable to the state. Otherwise the fourteenth amendment would apply equally to private citizens; that the fourteenth amendment is a restriction only on the states has not been seriously questioned since the Civil Rights Cases. $^{32}$

The question then becomes, are there other areas of permissive private behavior which may be imputed to the state? More specifically, must a group or individual exercise an exclusively governmental function before constitutional restrictions will be applied or are there other relations between private behavior and the state which will result in permissive behavior being labelled "state action"? Will the white primary cases and Marsh v. Alabama be further extended?

A handful of other Supreme Court cases suggest that they will. To the more theoretical minded these other cases will be exasperating. It is difficult to find in them any underlying principle which has application to fact situations other than their own. Some-Shelly $v$. Kraemer $^{33}$ and other restrictive covenant cases ${ }^{34}$-are difficult to understand even in their own terms. They are too few to form a related pattern. Together they might be characterized as unpatterned jabs into the future. They clearly go beyond the cases thus far discussed, yet it is difficult to ascertain the dimension in which they do so. All that we can safely say is that they prophesy that the final chapter in the saga of "state action" has not yet been written.

The trepidation with which even the United States Supreme Court has undertaken to develop the concept of "state action" is illustrated in Steele v. Louisville \& N.R.R. ${ }^{35}$ The Railway Labor Act requires an employer to recognize a union chosen by a majority of a craft as the

31. 345 U.S. at 477 (concurring opinion) (emphasis added); cf. Truax v. Corrigan, 257 U.S. 312 (1921).

32. 109 U.S. 3 (1883).

33. 334 U.S. 1 (1948).

34. Barrows v. Jackson, 346 U.S. 249 (1953) ; Rice v. Sioux City Memorial Park, Inc., 245 Iowa 147, 60 N.W.2d 110 (1953), aff'd by an equally divided Court, 348 U.S. 880 (1954), order vacated and cert. dismissed, 349 U.S. 70 (1955).

35. 323 U.S. 192 (1944). 
exclusive bargaining agent. ${ }^{38}$ A local Brotherhood of Locomotive Firemen and Enginemen entered into an agreement with the railroad which effectively limited the employment of Negroes as firemen and looked to their eventual complete exclusion. The Court held:

"[T]he Railway Labor Act imposes upon the statutory representative of a craft at least as exacting a duty to protect equally the interests of the members of the craft as the Constitution imposes upon a legislature to give equal protection to the interests of those for whom it legislates. . . Here the discriminations based on race alone are obviously irrelevant and invidious. Congress plainly did not intend to authorize the bargaining representative to make such discriminations." ${ }^{37}$

Had Congress so intended, "constitutional questions arise," 38 but the opinion appears to go off on the statutory ground. ${ }^{39}$ However, the implication seems to be that the Constitution as well as Congress requires the union to protect the rights of its Negro and white members indiscriminately, since the union is acting for the Government. ${ }^{40}$

If this is true, here again is permissive action of a private group circumscribed by constitutional restraints. It is difficult to conceptualize the nexus with the state that requires this result. Why is a business corporation, authorized to do business by the state, not subject to constitutional limitations, while a union, authorized as an exclusive bargaining representative, is so limited? The answer seems to lie somewhere in the word "exclusive." An exclusive bargaining power is a special authorization which impinges on the freedom of others to represent themselves. Employees and employers have a right to bargain with each other which even Congress could not totally abrogate; when it undertakes to regulate this right by authorizing an exclusive bargaining agent, Congress must do so without unreasonably emasculating the right. The vehicle through which this is assured is to impose constitutional restrictions on the bargaining agent by treating it as an agent of the Government. This then is another example of the vital relation between a private group and the government which makes the private group the agent of the government and thus subject to constitutional limitations.

36. 44 STAT. 577 (1926), 45 U.S.C. \& 152 (1952).

37. 323 U.S. at 202-03.

38. $I d$. at 198.

39. Justice Murphy, concurring, criticized the Court for this hedging: "[The case] raises a grave constitutional issue that should be squarely faced. ... If the Court's construction rests on this basis [of constitutional requirement], I agree. But I am not sure that such is the basis." Id. at 208-09.

40. The Steele case arose under the fifth amendment; the principles are the same. 
An even more cryptic case is Shelley $v$. Kraemer. The owner of real property subject to a fifty-year covenant restricting its use and occupancy to members "of the Caucasian race" sold the property to the Shelleys, Negroes. The owners of other property subject to the restrictive covenant brought suit to restrain the Shelleys from taking possession or title. The Supreme Court held that enforcement of this agreement by the state courts constituted state action.

The state's concern with the agreement was only the protection of property and contractual rights; the covenant's contents were irrelevant. An even more vexing aspect of the case is the difficulty of logically limiting its application. Does it apply whenever a party takes a dispute to court? Does it apply only to contracts? Only between willing buyers and willing sellers? Or only to contracts involving restrictive covenants on land? And what reasoning supports any of these limitations?

We shall return to the Shelley case. Our concern with it here is to illustrate that the Supreme Court intends not to limit the concept of state action but to expand it. That the Court does not intend to retreat from Shelley is made clear by Barrows $v$. Jackson, ${ }^{41}$ which held unconstitutional not only specific performance of a restrictive covenant but also the awarding of damages for its breach. ${ }^{42}$

Our next inquiry is, what other connections between a private group and the state are likely to result in "state action"? To determine this we shall examine the decisions and underlying theories of state and lower federal courts. Using the opinions we have discussed as their guides, these courts have applied the term "state action" to a myriad of fact situations. From these cases may be sifted two relationships between the private individual or group and the state which should result in "state action."

\section{The "State Property" Theory}

When public property is used for public purposes the user should be subject to constitutional restrictions as to its use, regardless of the property relationship between the state and the user. The state should be under a constitutional obligation to see that its property is used in only the same manner as the state could use it directly; a lease or trust should not be allowed to obscure constitutional rights. A prop-

41. 346 U.S. 249 (1953).

42. Two other cases which present problems similar to those in Shelley but add little to the discussion here are Public Util. Comm'n v. Pollak, 343 U.S. 451 (1952) and Rice v. Sioux City Memorial Park, Inc., 245 Iowa 147, 60 N.W.2d 110 (1953), aff'd by ait equally divided Court, 348 U.S. 880 (1954), order vacated and cert. dismissed, 349 U.S. 70 (1955). 
erty relationship between the state and the private party should be sufficient to result in "state action."

These propositions are suggested initially by two swimming pool cases, Culver v. City of Warren ${ }^{43}$ and Lazerence v. Hancock. ${ }^{44}$ In each a municipality leased a city pool to a lessee who refused the facilities to Negroes. In each case the court found that the city was using the lease as a device to avoid its constitutional responsibilities: there was a history of social tensions in connection with opening the pool, the rent was nominal. In Culver the city even maintained the pool.

The court in Culver found that "the real purpose of the lease to a private club, however it may have been disguised, was to exclude colored people from the use of this recreational facility." 45 Later, the court spoke of "piercing superficial forms" and a "colorable leasing arrangement," 46 and concluded that the lessee was "a mere agent or instrumentality through which the City of Warren operated the swimming pool." 47

\section{In Lazerence $v$. Hancock the court observed that:}

"Justice would be blind indeed if she failed to detect the real purpose in this effort of the City of Montgomery to clothe a public function with the mantle of private responsibility. 'The voice is Jacob's voice' even though 'the hands are the hands of Esau.' It is clearly but another in the long series of stratagems which governing bodies of many white communities have employed in attempting to deprive the Negro of his constitutional birthright; the equal protection of the laws." 48

It will be noted that these cases contain an element not mentioned in the propositions at the head of this section, namely, that the city had an unconstitutional purpose in effecting the leasing arrangement. The lease was entered into in an attempt to exclude Negroes. Should courts look behind the property relationship in order to determine the city's intent or purpose before passing on the constitutional question of "state action"? Different courts have answered the question differently.

\section{Intent Under the "State Property" Theory}

In Kern v. City Comm'rs ${ }^{49}$ the state action question was decided on the pleadings, which did not contain an averment as to the city's purpose in leasing its pool. Furthermore, the lessee operated the pool

43. 84 Ohio App. 373, 83 N.E.2d 82 (1948).

44. 76 F. Supp. 1004 (S.D.W. Va. 1948).

45. 84 Ohio App. at 381,83 N.E.2d at 87 .

46. Id. at $381-82,83$ N.E.2d at 87 .

47. Id. at 386,83 N.E.2d at 88 .

48. $76 \mathrm{~F}$. Supp. at 1008.

49. 151 Kan. 565 , 100 P.2d 709 (1940) (mandamus was denied for reasons immaterial here). 
for profit and paid $\$ 1,000$ per season rent (in 1936). He was required to save the city harmless against all losses and to be insured therefrom. Nevertheless, the court held the lessee subject to constitutional restrictions. Discriminatory intent thus seems unnecessary.

A recent case which would support this reasoning is Department of Conservation and Development v. Tate. ${ }^{50}$ The Negro plaintiffs were refused admittance to a state-owned park. When they sued to enjoin this as a violation of their constitutional rights, the state began to arrange a lease of the property such as might avoid the contemplated decree. The plaintiffs amended their prayer to add a request for an injunction to restrain any lease that would allow the lessee to discriminate. Although the state sought to justify the lease on purely economic grounds, its true purpose was evident to the court. However, the injunction did not distinguish between a lease for the purpose of excluding Negroes from the park and a lease executed for any other purpose. Rather, the permanent injunction contained this broad language: "If said park or any part thereof is leased, the lease must not, directly or indirectly, operate so as to discriminate against the members of any race." 51 Further, it enjoined any "lessees" from denying to "any person of the Negro race, by reason of his race and color, the right to use and enjoy the facilities." 52

On the other hand, in Easterly v. Dempster ${ }^{63}$ it was held that where the city had leased its golf course to a private corporation for financial reasons-the city had lost $\$ 26,700$ in operating the golf course in the previous four years-rather than to deprive the plaintiffs of their constitutional rights, any discrimination by the lessee was that of a private party and not of the state.

It would seem that the question of the state's purpose in allowing a private group or individual to discriminate is too tenuous an inquiry on which to turn constitutional rights. Attempts to disguise purposes would become common; regardless of a court's indicia for determining purpose, a city could tailor those factors to serve its objective. Who is to say that a city has one purpose in effecting a lease when it has been losing money in operation of the property or project but another when the lease is executed from the time of the project's inception?

Moreover, even if the city's intent could be easily and with certainty ascertained, it is irrelevant. A municipality perspicacious enough to know the effect of what it does should not have less freedom

50. 231 F.2d 615 (4th Cir.), cert. denied, 352 U.S. 838 (1956).

51. $I d$. at 616 .

52. Ibid.

53. 112 F. Supp. 214 (E.D. Tenn. 1953). 
of action than the municipality that is either too ignorant or naive to recognize that its support is being lent to discrimination.

Support for this position may be found in two Supreme Court cases. In Marsh v. Alabama the Court did not inquire into whether there was behind the trespass conviction a state or municipal policy to discriminate against any particular individual or sect. On the contrary, it seems clear that the state's only concern in enacting and enforcing the "loitering" statute was the protection of property interests. ${ }^{54}$

This view also seems bolstered by the Supreme Court's reversal of Sweeney $v$. Louisville. ${ }^{55}$ The City of Louisville rented a theatre for the summer to the Louisville Park Theatrical Association. The lessee refused to admit Negroes to performances. The lower court refused relief on the ground that, under the separate-but-equal doctrine, there was no denial of equal protection because Negro organizations were as free to rent the facilities of the theatre as whites. The lower court, therefore, did not reach the question of whether the lessee was bound by constitutional limitations. In a per curiam decision the Supreme Court vacated the judgment and remanded the case for consideration in the light of Brown v. Board of Education, ${ }^{56}$ which repudiated the separate-but-equal doctrine in elementary and secondary schools. In so indicating that there may have been a denial of equal protection that would merit relief, the Court implicitly recognized that the lease to a private organization would not preclude such relief, for otherwise the Brown decision could not affect the result. Thus, there was here "state action" despite the lease. If this is true, the case is particularly meaningful because there is no indication from the record that the primary purpose or intent of the city was to provide for a segregated theatre audience. While we cannot be sure just what the Supreme Court meant by its decision, it is an indication that property leased from a municipality may not be used in a discriminatory manner regardless of how the city may justify it.

It should be noted that the "state property" theory could have been applied to several other cases, but was not. In two such cases the theory was unnecessary, since "state action" was found on more traditional grounds. ${ }^{57}$ However, in a third, Norris v. Mayor, ${ }^{58}$ the

54. The same may be said of Shelley v. Kraemer, 334 U.S. 1 (1948) and cases in its train. See pp. 234-36 infra.

55. 102 F. Supp. 525 (W.D. Ky. 1951), aff'd sub nom., Muir v. Louisville Park Theatrical Ass'n, 202 F.2d 275 (6th Cir. 1953), rev'd per curiam, 347 U.S. 971 (1954).

56. 347 U.S. 483 (1954).

57. Kerr v. Enoch Pratt Free Pub. Library, 149 F.2d 212 (4th Cir.), cert. denied, 326 U.S. 721 (1945); Nash v. Air Terminal Services, Inc., 85 F. Supp. 545 (E.D. Va. 1949).

58. 78 F. Supp. 451 (D. Md. 1948). 
court failed to consider the facts from this approach. The result, it is submitted, is erroneous. The court held no "state action" despite the fact that the Maryland Institute, a trade school charged with a discriminatory admissions policy, leased a municipal building from the city for $\$ 500$ a year. The admitted fair rental value was $\$ 12,000$ per annum.

Before considering the application of the "state property" theory to the Girard case, at least two qualifications of the theory should be observed. The first is suggested by the Norris case. There may be a situation where the use of state property is such an incidental part of the operation that it would be unfair to characterize the entire project as state action. In such a case damages for past violations should not be allowed against the private organization. However, an injunction should lie against further unconstitutional use of state property. ${ }^{59}$

A second qualification is incorporated in the statement of the theory at the beginning of this section: The private organization must use the property for public purposes. A tenant who rents his apartment from a state-owned housing development should not be subject to the same constitutional limitations imposed on the state. Two elements readily suggest themselves to determine whether the use is a public or private one: Is the activity one which is commonly undertaken by the state? Is the activity open to the public or a large segment thereof? These are not suggested as mechanical tests, but as guides. Similar concepts have been developed case by case to distinguish public from private corporations. ${ }^{60}$ Borderline cases readily suggest themselves, e.g., a lease of state owned property to a department store that refuses to employ Negroes. The judicial vehicle of decisions is an appropriate one for the development of this concept. An orphanage, school or recreational facilities seem clearly to fall on the public side of the line.

\section{"State Property" and the Girard Estate Case}

Several reasons may be urged as to why the state property theory should not apply to the Girard Estate case.

The first objection is that the City of Philadelphia owns title only as trustee. As the Orphans' Court in its en banc opinion stated, "The possession of the City, as trustee, is the possession of the testator, Girard." 61 The short answer to this may be found in Justice Frank-

59. The latter remedy was sought and denied in the Norris case. The remedy against the state has been labeled intensive enforcement; against the private party, extensive enforcement. See Note, 61 HARV. L. REv. 344, 347 (1948).

60. See Trustees of Dartmouth College v. Woodward, 17 U.S. (4 Wheat.) 518 (1819); cf. Kedroff v. St. Nicholas Cathedral of Russian Orthodox Church, 344 U.S. 94 (1952); Vermillion v. Woman's College, 104 S.C. 197, 88 S.E. 649 (1916). 1956).

61. Girard Estate, 4 Pa. D. \& C.2d 671, 717-18 (Philadelphia County Orphans Ct. 
furter's opinion in Marsh v. Alabama: "Title to property as defined by State law controls property relations; it cannot control issues of civil liberties. . . . 62 The longer answer is that a gift to the city in trust for charitable purposes is no different in substance from a gift in fee for the same purposes. There are limits to the uses to which a city may put its property regardless of whether the city received title by purchase or gift. A municipality may administer a trust only "for public purposes, germane to its object." 83 While there are advantages to a city's serving as trustee, ${ }^{64}$ there are concomitant restrictions. A testator who devises or bequeaths property to a city must be taken to know that these restrictions thenceforth apply. What a city may not do directly it should not be permitted to do indirectly by accepting gifts for the unlawful use. This principle is not unknown to the law. It has been held, for example, that "municipal corporations cannot hold land in trust for religious purposes." 65

The second argument against the theory's application to the Girard Estate case is that the restriction against Negroes was placed on the property by Girard rather than by the city. This is simply another way of saying that the city had no purpose or intent to discriminate, that the discrimination originated solely with the private individual. However, once the gift is complete, the property is no different from other city property. That the city's purpose or intent in allowing its property to be used in a discriminatory manner is irrelevant has already been dealt with ${ }^{66}$ and will be discussed in greater detail in the succeeding section. ${ }^{67}$

Finally, it is urged that one cannot speak of a city's obligation to see that property is used within certain limits when the city received the property with other obligations already attached to the property. We may not speak of obligations, so this reasoning runs, unless there is a freedom to fulfill them. However, there may be a constitutional obligation to refuse to accept title or, in the alternative, to obtain a court decree that the restriction be removed. Thus the city's obligation may be easily met in this manner; it has thus been required and met before. ${ }^{68}$

62. 326 U.S. at 511.

63. Philadelphia v. Fox, 64 Pa. 169, 181 (1870); see 3 Dillon, Munictpar CoRporations $\$ 982$ (5th ed. 1911); 10 MCQullian, Municipal CoRporation $\$ 2825$ (3d ed. 1950).

64. See note 105 infra.

65. City of Maysville v. Wood, $102 \mathrm{Ky} .263,268,43$ S.W. 403, 404 (1897); see Bullard v. Shirley, 153 Mass. 559, 27 N.E. 766 (1891).

66. See pp. 222-24 supra.

67. See pp. 231-36 infra.

68. Bullard v. Shirley, 153 Mass. 559, 27 N.E. 766 (1891); see City of Maysville v. Wood, $102 \mathrm{Ky} .263,43$ S.W. 403 (1897). 


\section{The Meaning of State Contacts}

In the earlier discussion of Supreme Court cases dealing with "state action" we noted that when a private group undertook to perform a public function that was considered an exclusive function of the state, such as voting or operating a municipality, the private group was held to be the agent of the state for constitutional purposes. Now we consider under what conditions, if any, a private group will be subject to the fourteenth amendment when it exercises a public function that is not considered the exclusive function of the state.

The theory advanced by which a private group may become subject to the fourteenth amendment might be denominated as the "state contacts" or "degree of control" theory. It may be stated as follows: Under some circumstances state contact, control and encouragement may be so intimately fused with the activities of a private group or individual in the performance of a public function that it seems fair to call the activity "state action" within the meaning of the fourteenth amendment. ${ }^{69}$

Such a theory is necessarily incorporated into the Constitution. So long as some public functions may be undertaken both by the state and by private citizens, a distinction must be made between them for purposes of the fourteenth amendment.

Education, the subject matter of the Girard Estate case, illustrates this point. We may pose two polar cases: A local public school system administered by elected officials and maintained by public funds is clearly subject to the equal protection clause. On the other hand, Miss Carter's Country Day School, managed by Miss Carter with her own funds, is just as clearly not subject to the fourteenth amendment. The theory stated in the preceding paragraph adumbrates a rule for distinguishing between the two polar cases and for deciding the more difficult cases that lie between.

Each borderline case must be decided on its own bottom by a careful scrutiny of all the contacts between the state and the private party, the degree of control exercised over the operation of the project and the encouragement given it by the state.

This process may be illustrated in the field of education by Parker v. University of Delaware. ${ }^{70}$ In finding that the University of Delaware was a state institution for purposes of the fourteenth amendment, the court considered the following factors: The University had its origin with the state legislature, several statutes had been passed relating

69. Cf. Berle, Limitations on Corporate Activity, 100 U. PA. L. Rev. 933, 948-51 (1952).

70. 31 Del. Ch. 381, 75 A.2d 225 (1950). 
to the University, the board of trustees was appointed by governmental officers, governmental officers by virtue of their public office are members of the board of trustees, the state contributes funds to the University. The court chose no one of these facts as crucial but considered their cumulative, conglomerate effect.

Within this context the "state property" theory discussed in the preceding section will be seen as one contact that may be deemed decisive. Perhaps as the "contacts" theory becomes more highly articulated by future decisions, we may isolate other factors or types of factors which may be equally decisive. Present case literature, however, has not proceeded that far. The types of public functions undertaken by private citizens are as varied as the functions of the state; the cases in which each function is considered are few.

\section{Judicial Viezes of State Contacts}

Different courts have dealt with state contacts sometimes more, sometimes less, sympathetically. The extent to which courts will "pierce superficial forms" has varied. A strict legalistic view is illustrated by Dorsey v. Stuyvesant Town Corp., ${ }^{71}$ where a low-rental housing development involving the investment of $\$ 90,000,000$ of private funds denied applications for rental to Negroes. The state contacts with the development have been summarized by Judge Fuld in his dissenting opinion:

"Not only did it [the state] fix their minimum rents and profits but it laid down careful limitations with respect to their financing and mortgaging, the selling or disposing of property or the altering of the structures. To the city governments, the statute gave authority to approve any plan for a proposed development and power to include, by contract, provisions for the 'operation and supervision of the project.' In addition, the City was enabled to use certain of its governmental powers to aid the work. It was empowered to condemn property by eminent domain in order to assemble the area to be rehabilitated, and then to convey the property to the redevelopment companies at cost; to close off and transfer public streets; and to grant tax exemptions on the improvements for a twenty-five year period." 72

The project would not have been substantially different had the city borrowed the funds from a private party at a fixed interest rate and constructed and managed the project itself.

71. 299 N.Y. 512, 87 N.E.2d 541 (1949), cert. devied, 339 U.S. 981 (1950).

72. Id. at 537,87 N.E.2d at 552 (references to sections of the statute have been omitted from the quotation). 
The New York Court of Appeals failed to find state action despite a persuasive contention by the dissent ${ }^{73}$ that a policy to discriminate was imputable to the state since the city knew when it approved the contract with Stuyvesant Town that Negroes would be excluded and the city excepted Stuyvesant Town from an ordinance forbidding racial discrimination in similar projects. ${ }^{74}$ The court distinguished all previous decisions by labeling the governmental support of discrimination in those cases as "direct" ${ }^{75}$ - one of the most distracting weaselwords known to the law-and characterizing the state contacts with Stuyvesant Town as "helpful cooperation." 78

By way of contrast, Kerr v. Enoch Pratt Free Pub. Library ${ }^{77}$ is the leading case piercing technical forms to find "state action." There, plaintiff was excluded because of her color from the Baltimore public library's employee training school. The library's origin may be traced to a private gift to the city in 1882 on condition that the city contribute $\$ 50,000$ annually to the library, that a self-perpetuating board of trustees be incorporated to manage the library, and that annual reports be made to the city. The city and state legislature passed the appropriate ordinances and acts to comply with the conditions. In 1907 a gift to the city by Andrew Carnegie for library purposes on condition that the city make substantial contributions was added to the funds of the corporation. Title to the property and monies of both gifts remained in the city, while management was vested in the board of trustees through the corporation. In 1927 the city floated a bond issue approved by the voters to increase the money available to the corporation. At the time of the suit the city was contributing over $\$ 800,000$ a year to the corporation, which managed what had grown into a system of libraries serving the entire city.

Salaries of the library staff are paid by the city's payroll office and charged to the library appropriation. Library employees participate in the municipal employees' retirement system. The library budget is

73. Id. at 536, 538, 87 N.E.2d at 551, 552-53.

74. Cf. Truax v. Corrigan, 257 U.S. 312 (1921). It has been suggested that certiorari was denied because this ordinance makes it impossible for the situation to arise again in New York. Cf. Rice v. Sioux City Memorial Park, Inc., 349 U.S. 70 (1955).

75. "All of the previous decisions, and those cited, might be distinguished in that they disclose the exertion of governmental power directly to aid in discriminating or deprivation of right. . ." 299 N.Y. at 533, 87 N.E.2d at 550.

76. "To say that the aid accorded respondents is nevertheless subject to these [constitutional] requirements, on the ground that helpful co-operation between the State and the respondents transforms the activities of the latter into State action, comes perilously close to asserting that any State assistance to an organization which discriminates necessarily violates the Fourteenth Amendment." Id. at 535, 87 N.E.2d at 551 .

77. 149 F.2d 212 (4th Cir.), cert. denied, 326 U.S. 721 (1945). 
submitted to municipal authorities for approval, along with a report to the city on the past year's proceedings, the condition of the library, and receipts and disbursements.

The court found that the library was an instrumentality of the state and therefore subject to constitutional restraints: the Negro plaintiff's application must be considered without regard to race or color.

It should be noted that the city's contribution to the library might have been made the sole basis for the decision in the Kerr case. Monetary contributions are simply a variant of the "state property" theory. The court, however, proceeding on the state contacts theory in a more general sense, considered the city's financial aid only as an element by which the city exercises control over the library. ${ }^{78}$ The court observed that:

"Even if we should lay aside the approval and authority given by the state to the library at its very beginning we should find in the present relationship between them so great a degree of control over the activities and existence of the library that it would be unrealistic to speak of it as a corporation entirely devoid of government character." 79

It concluded rhetorically, "How then can the well-known policy of the Library . . . be justified as solely the act of a private organization when the state, through the municipality, continues to supply it with the means of existence." 80

\section{State Contacts in the Girard Estate Case}

The Girard Estate case combines many of the factors which the courts considered important in both the Parker and the Kerr cases. The contacts between the College and the City of Philadelphia are many and varied: An agent of the city, the Board of Directors of City Trusts, actually manages Girard College (thus presenting a closer management relationship with the state than in Parker or Kerr). Several statutes have been passed in regard to the College (as in Parker), including one which was thought necessary to allow the city to serve as trustee. ${ }^{81}$ The administrators of the school are appointed

78. See $i d$. at 217.

79. Id. at 219 .

80. Ibid.

81. PA. Stat. AnN. tit. 53, § 6792 (Purdon 1931) (Act of Feb. 27, 1847). Other statutes relating to the Girard Trust are: Id. \$6791 (Act of March 24, 1832); id. $\S 6798$ (Act of June 30,1869 ). The city has passed many ordinances relating to the College and Girard Trust. 
by governmental officers (as in Parker-in Kerr only the original board of directors was appointed by the city, after which the board became self-perpetuating); governmental officers, the Mayor and President of the Councilmanic Chamber, are ex officio members of the board (as in Parker). The legislature regulates the method of selection of the managing body (as in Parker); annual reports are made to a governmental body (as in Kerr); and a governmental officer audits the books of the project (as in Kerr). Girard College originated in a gift in trust to the city, while in Kerr the library originated in a gift on condition to the city.

From the standpoint of sheer involvement, one can hardly imagine greater contact between Girard College and the City of Philadelphia. Even its daily operations are controlled by the city through its agents.

On the other hand, there are two factors which distinguish the Girard Estate case from Kerr and Parker: First, the city contributes not a penny to Girard College, while in Kerr and Parker large sums were contributed by the city and state. Secondly, in Girard the discrimination is not practiced through exercise of the managers' volition. The discrimination is practiced as the specific requirement of Stephen Girard, a private citizen. In Kerr and Parker the boards of directors charged as state agents could have admitted Negroes to their respective institutions had they so chosen. In Girard, however, there is even some doubt as to whether the state could remove the restriction by statute. ${ }^{82}$

Appraisal of the factors thus arrayed on either side requires a determination of their significance for finding state action. What is the significance of such contacts? The answer is deceptively simple: To find state action we must find that the state is the effective source of the discrimination.

It is deceptively simple because of the temptation to dispose of the case merely by saying that here the source of the discrimination is Stephen Girard, and not the City of Philadelphia, just as it would have been simple to say that the source of discrimination in the Kerr case was the independent, self-perpetuating board of trustees, or in Smith v. Allweright that the source of the discrimination was the Democratic Party and not the State of Texas.

\section{The State as the Effective Source of Discrimination}

The state's purpose in permitting a private party to take the condemned action may, but need not necessarily, be to accomplish dis-

82. See Trustees of Dartmouth College v. Woodward, 17 U.S. (4 Wheat.) 518 (1819); Cary Library v. Bliss, 151 Mass. 364,25 N.E. 92 (1890); Brown v. Hummel, 6 Pa. 86 (1847) ; cf. Conovaro v. Brothers, 326 Pa. 76, 94, 191 Atl. 140, 149 (1937). 
crimination. When the state's purpose in allowing the action is to achieve discrimination, state action clearly results. Thus in Smith $v$. Allwright, where the state's purpose in freeing the Democratic Party from state regulation was to have an all-white primary, the private group was held to the same standards as the state. In the swimming pool cases, ${ }^{83}$ where the lease was effected to deprive Negroes of the use of city pools, the lessee was held bound by the same restrictions as the state.

But the policy of a state in permitting discrimination may be expressed more subtly. In the conduct of elections, a policy to discriminate will be imputed to the state even though the state is guilty only of the "abdication" of its power to control elections. ${ }^{84}$ Similarly, in Kern v. City Comm'rs a policy to discriminate was imputed to the state from the mere rental of a swimming pool even though the city's purpose was only to use the property productively in a proprietary capacity. The city had an obligation to see that its property was used in a non-discriminatory manner. If it failed so to do, a policy of discrimination was imputed to it.

In other words, as the concept of "state action" expands, greater obligations are placed on the state to insure that activities with which it is associated do not discriminate. If the private party wishes to discriminate it may, but the state must withdraw its support.

Thus, in determining whether the state is the effective source of discrimination the relationship with the state is all that is important. It is irrelevant that the private party also is responsible for the discrimination; only by showing that the state is not responsible may constitutional restraints be avoided.

\section{State Grants of Special Powers or Privileges}

Just as we have argued that when a state allows a private party to use its property the state is obligated to insure a non-discriminatory use of the property, so when a state grants a special power or privilege to a party the state is obligated to insure that the power is used in a non-discriminatory manner. When a state grants to one of its citizens an unusual power or privilege, it is presumably acting in the public interest. This is the state's way of furthering the public weal; by the grant of power or privilege the state is fulfilling its function. In so doing, it becomes a party to, a partner in, the fostered project.

83. Lawrence v. Hancock, 76 F. Supp. 1004 (S.D.W. Va. 1948) ; Culver v. City of Warren, 84 Ohio App. 373, 83 N.E.2d 82 (1948).

84. Terry v. Adams, 345 U.S. 461, 477 (1953). 
The grant of an unusual power or privilege may thus result in "state action."

What powers and privileges result in the state's becoming a party to the project are difficult to determine. Only a case by case analysis can suffice. In each case the question is: Does the power or privilege confer on a private party an especially advantageous position so that in substance the state can be said to be taking a part in the project?

There is no fool-proof method of distinguishing a power or privilege on the one hand from mere regulation on the other. The power or privilege may be viewed as an activity open to all comers providing they meet certain standards and comply with specified regulations. For example, in Dorsey v. Stuyvesant Tozen Corp., where the statute was cast in the form of regulation of companies wishing to construct public housing developments, if any company met the requirements it received the privileges and powers. However, it should not be too difficult for courts to penetrate the form to determine the essential relationship between the state and the private party. In Dorsey a special tax exemption and the power of eminent domain were granted to the private party to foster and encourage the project. The extreme example of the grant of a power is Steele $v$. Louisville \& $N$. $R . R$., where a union was given the right of exclusive representation. In contrast, the control exercised by the Federal Communciations Commission over a radio station has been held to be mere regulation. ${ }^{85}$ But on the other hand, the franchise granted to a public utility would seem clearly a power or privilege resulting in state action. The authority placed in a board of bar examiners to decide who may practice law in a state might also be considered such a power, but it has been held otherwise. ${ }^{86}$

Another problem that may arise when "state action" results from the granting of a power or privilege involves the relationship between the power or privilege and the respect in which discrimination is practiced. For example, where the power of eminent domain is granted, it may be argued that state action is present only in the exercise of the power itself. It would seem that this argument fails to recognize that by the grant of the power the state becomes a party to the ultimate project, since the power is granted pursuant to the state's design to foster that project. Nevertheless, a difficult question is presented where the discriminatory practice is only remotely related

85. McIntire v. Wm. Penn Broadcasting Co., 151 F.2d 597 (3d Cir. 1945), cert. denied, 327 U.S. 779 (1946).

86. Mason v. Hitchcock, 108 F.2d 134 (1st Cir. 1939). Query whether the bar examiners could require that all successful applicants be members of the Caucasian race? 
to the granted power or privilege. Such a problem was posed in Johnson $v$. Levitt \& Sons, Inc. ${ }^{87}$ There, plaintiffs alleged refusal of their application to purchase homes in Levittown solely on the ground of their color. The claim in federal court was that by the Government's guarantee of purchasers' mortgages through the VA and FHA, the project itself became governmental action and was therefore subject to constitutional restraints against racial discrimination. The federal agencies do not guarantee a mortgage unless the property meets detailed construction requirements and unless the terms and amount of the mortgage meet other specifications. Plaintiffs contended "that the regulation and control exercised by the federal agencies in Levittown is so extensive, the relationship between the federal agencies and Levitt is so intimate, the federal aid in this instance so crucial to the development of a community like Levittown and federal involvement in Levitt's determinations so great that the actions of Levitt must be deemed to be the acts of the federal agencies." 88 The court dismissed the complaint for lack of a federal question.

One of the difficulties in finding "state action" in Levitt is that the relationship between the discrimination and the guaranteeing of the mortgage is so distant. The government agencies only guarantee the purchaser's mortgage; the seller may or may not be the mortgagor. The government guarantee is for the purpose of enabling those qualified to finance the purchase of their individual homes. Notwithstanding, it may be suggested that this is only the legal form of the transaction, that in substance the mortgage guarantees are simply a bit of social engineering aimed at encouraging parties like Levitt to construct new housing developments and that the government mortgages were an integral part of the entire project. Whether this is true so as to make the-government a party to the project and the effective source of the discrimination is a close question.

\section{Use of State Facilities}

Finally, a policy condoning discrimination may be imputed to the state, thus making it the effective source of discrimination, when the state allows its facilities to be used to practice discrimination. This appears to be the holding of the hallmark of "state action" cases, Shelley ข. Kraemer. ${ }^{89}$

A major difficulty commentators have found with Shelley is in determining when discriminations may be enforced by a court. It has

87. 131 F. Supp. 114 (E.D. Pa. 1955).

88. $I d$. at 116.

89. 334 U.S. 1 (1948); see p. 221 supra. 
been suggested that the Shelley rationale may be extended to the point where the only private discrimination that may be practiced is that voluntarily accepted by the parties, and that once the sanction of the court is sought, state action results. ${ }^{90}$ By this view, a seller could not refuse to sell to a Negro solely on the basis of his color if the Negro sought court aid in enjoining the practice. ${ }^{21}$

Most observers would not agree with this formulation. Yet it is difficult to find another logical limit to the underlying proposition that whenever private discrimination is "supported by the full panoply of state power," ${ }^{92}$ state action results. Or to use the language of another case, "When authority derives from Government's thumb on the scale the exercise of that power by private citizens becomes closely akin, in some respects, to its exercise by Government itself." ${ }^{23}$

It seems clear, however, that the principle will not be applied to the extent indicated above. Otherwise we would find state action in Girard Estate by the very refusal of the Orphans' Court to grant some kind of relief. A similar argument could be advanced in any case where a court rejects a contention that "state action" existed. Several limits to the Shelley case have been suggested.

The Shelley case may be limited to cases involving restrictive covenants. In its historical setting, the case is one of a series which have struck at attempts to limit occupancy and use of real property to white people. ${ }^{94}$ Perhaps because of this history involving state at-

90. Huber, Revolution in Private Law?, 6 S.C.L.Q. 8 (1953).

91. Id. at 26-27.

92. 334 U.S. at 19. (1950).

93. American Communications Association, CIO v. Douds, 339 U.S. 382, 401

94. The cases are legion. See, e.g., Gandolpho v. Hartman, 49 Fed. 181 (C.C.S.D. Cal. 1892) (a case largely ignored, holding, as Shelley, that a state may not enforce restrictive covenants); Buchanan v. Warley, 245 U.S. 60 (1917) (holding unconstitutional a city ordinance denying to Negroes the right to occupy houses in blocks in which the majority of houses were occupied by whites, and vice versa); Corrigan v. Buckley, 271 U.S. 323 (1926) (in effect reversed by Shelley); Richmond v. Deans, 281 U.S. 704 (1930).

Cases following Shelley are Barrows v. Jackson, 346 U.S. 249 (1953) (suit for damages based on violation of restrictive covenant could not be maintained); Rice v. Sioux City. Memorial Park, Inc., 245 Iowa 147, 60 N.W.2d 110 (1953), aff'd by an equally divided Court, 348 U.S. 880 (1954), order vacated and cert. dismissed, 349 U.S. 70 (1955) (restrictive covenant may be used as a defense to a tort suit for damages); Charlotte Park and Recreation Comm'n y. Barringer, 242 N.C. 31, 88 S.E.2d 114 (1955) (upholding enforcement of a fee simple determinable subject to the condiition subsequent that the land not be used by Negroes); Clifton v. Puente, 218 S.W.2d 272 (Tex. Civ. App. 1948) (restrictive covenant providing for forfeiture no defense to an action of ejectment by the purchaser on sale or lease to a Mexican). For general discussions of the problem see Lathrop, The Racial Covenant Cases, 1948 WIS. L. REv. 508; Ming, Racial Restrictions and the Fourteenth Amendment: The Restrictive Covenaint Cases, 16 U. CHI. L. REv. 203 (1949).

For maneuvers to evade the effect of Shelley, see Walker, Judicial Enforcement of Racial Restrictive Covenants-The Spurious Expansion of "State Action," 59 VA. B.A. Rep. 231 (1948); Note, 37 Calif. L. Rev. 493 (1949). 
tempts to create "Negro zoning laws," a policy of discrimination will be imputed to the state in enforcing such private agreements. But McGhee v. Sipes, ${ }^{95}$ the companion case to Shelley, came from Michigan, a state where there was no such history. While a policy of discrimination may be imputed to the state because state enforcement of private agreements allows the state to accomplish indirectly what it could not accomplish by statute or ordinance, ${ }^{96}$ this is true of almost all private discrimination.

Secondly, the Shelley holding may be limited to contract cases (or perhaps contract cases involving restrictive covenants) where there is a willing buyer and a willing seller. ${ }^{97}$ According to this theory the Shelley decision rests on the fact that there were two contracts, a contract of sale and a contract restricting sale, only one of which could be fulfilled. In deciding which of such contracts is binding, a court may not use its power to enforce the discriminatory one; between the two property rights claimed, the civil right turns the balance. While this theory might be a basis for limiting Shelley's application, it hardly clarifies its meaning since the discriminatory contract was earlier in time and in terms controls the second. Without considering the civil right, there is no doubt as to which way the scales dip.

Perhaps the answer is that the state may not order discrimination by its decree, but when it is called upon to take affirmative action to prevent discrimination it may refuse to do so. The problem then becomes: When does a court decree order discrimination? Most often a decree ordering discrimination would involve a contract or property right, and to this extent the limitation suggested above might be valid; however, it still does not identify the crucial issue. The theory that a court may not enforce, but need not prevent, discrimination may explain the decision in Jackson $v$. Barrows and help us to understand the court's difficulty with Rice v. Sioux City Memorial Park, Inc. ${ }^{98}$ Would allowing a restrictive covenant to be used as a defense in a tort suit be in effect enforcing discrimination? ${ }^{99}$

95. 334 U.S. 1 (1948).

96. Cf. Terry v. Adams, 345 U.S. 461 (1953).

97. "These are cases in which the States have made available to such individuals the full coercive power of government to deny to petitioners, on the grounds of race or color, the enjoyment of property rights in premises which petitioners are willing and financially able to acquire and which the grantors are willing to sell." 334 U.S. at 19 .

98. 245 Iowa 147, 60 N.W.2d 110 (1953), aff'd by an equally divided Court, 348 U.S. 880 (1954), order vacated and cert. dismissed, 349 U.S. 70 (1955).

99. If this view of Shelley is accepted, the decision in Charlotte Park and Recreation Comm'n v. Barringer, 242 N.C. 31, 88 S.E.2d 114 (1955), would seem erroneous. 
State Contacts and the Effective Source of Discrimination in the Girard Case

The question of when the state may allow its judicial facilities to be used to enforce discrimination is really tangential to the problem posed by the Girard Estate case. For once it is established that there are some cases in which the state may not allow its courts to be used to impose discrimination, it would seem that it may not permit its facilities as trustee to be used to carry out a discriminatory scheme.

Thus, despite the fact that Girard supplied all the funds for the College and despite the fact that he decreed the discriminatory practice, the state is the effective source of the discrimination if it allows its facilities to be used to carry out the plan. This, then, is the significance of the relationships and contacts between Girard College and the state. When the state allows its managerial facilities to be used to operate a discriminatory scheme, state action results.

Just as in Shelley the enforcement of the decree would result in the state's performing the physical act of discrimination, so in Girard the management by the city results in the city's performing the physical act of discrimination. In Shelley the state would have had to remove the Shelleys from the land to enforce the decree; in Girard the city would close the doors of Girard College to the Negro petitioners.

In several respects the Girard Estate case is even stronger than Shelley: In Shelley the court was called on only to enforce the private discrimination; in Girard the state is called upon to carry out and manage the discriminatory scheme. In Shelley the court stood ready to enforce any private agreement that was otherwise legal; in Girard the city's service as trustee is not available to private citizens for their private purposes. The trust must be germane to the purposes of the city. In fulfilling these purposes, the city may not constitutionally discriminate against Negroes. In Shelley the parties to the agreement were private individuals; in Girard, by accepting the trusteeship, the state became a party to the agreement.

We have noted that private action is more likely to be stamped with the imprimatur of state action if the private activity serves a public function. In the Girard Estate case, the College serves a public function. The contract in Shelley concerned only the parties to the agreement.

It would seem, therefore, that if Shelley has any application to a unique fact situation, Girard would be a case to apply it. 
Transcending legal forms, Girard College is simply the gift of a unique school for orphan boys. Since the school henceforth belongs to the city, the city may not accept the gift unless the school is subject to the same constitutional restrictions as are other city schools.

\section{The Pennsyluania Supreme Court Decision}

The Pennsylvania Supreme Court took an entirely different approach to the constitutional problem raised by the Girard Estate case than has been here presented. By focusing on a different question, the court reached a different conclusion.

The court presented the issue as follows: "The question then, is whether the limitation in Girard's will to white children as the beneficiaries of his college or orphanage, although undoubtedly lawful at the time of the execution of the will and of his death, has become invalid as a result of the adoption of the Fourteenth Amendment. " 100 In thus directing itself to the validity of the restrictive provision the court avoided the narrower and more perplexing issue. The first and only constitutional question is whether city trusteeship violates the fourteenth amendment. Only then does the question arise of what is to be done-by way of removing the restriction against Negroes or appointing a new trustee-and it is only to this question that the validity of the restriction itself is pertinent. The constitutional issue is simply whether the city may serve as trustee of a charitable trust whose beneficiaries are limited to white children.

The constitutional issue is not whether Negroes must be admitted to Girard College; it does not concern a man's right to dispose of his property as he sees fit (although several pages of the opinion are devoted to this question); it does not involve an attempt to delete the word "white" from the will; it is solely whether the city may constitutionally serve as trustee. It is the remedy-not a constitutional question-that is concerned with what is to be done if the city cannot serve under the present terms of the will.

The court, however, having stated the problem as the constitutional validity of the restriction, proceeds to treat the case as though it were a desegregation case in which the narrower issue were whether Girard College is a public school to which Negroes must be admitted or a private school. Accordingly, the court concludes that "all provisions of the will show that it was not intended to be a public school. . . ."101

100. In re Estate of Stephen Girard, 127 A.2d 287, 291-92 (Pa. 1956).

101. Id. at 293. 
The problem of "state action" is much subtler than this. If the approach of this court were applied in Steele v. Louisville \& N.R.R., ${ }^{102}$ we would simply have to determine whether the union were a public or private organization. Clearly if the problem were posed in this way no "constitutional questions arise." 103 The application of the emergent concept of "state action" to any particular fact situation requires a careful examination of the relationship between the State and the resultant discrimination. This examination is not enhanced by confusing the constitutional problem of whether the city may serve as trustee under the present terms of the trust with the issue of the remedy-whether a new trustee will be appointed or Negroes admitted.

Although the Court fails to recognize this in dealing with the constitutional question, it nevertheless gives to the remedy separate treatment in which it does distinguish between the constitutional problem and the remedy. It indicates that even if city trusteeship were unconstitutional, the petitioners would still win only a pyrrhic victory since the remedy would be the appointment of a private trustee rather than the admission of Negroes to Girard College. ${ }^{104}$ The remedy, so long as it is constitutional, would, of course, be a matter of state law.

Under the doctrine of $c y$ pres, ${ }^{105}$ the court could either appoint a private trustee or admit Negroes in order to cure the present trustee's

102. 323 U.S. 192 (1944).

103. $I d$. at 198.

104. In re Estate of Stephen Girard, 127 A.2d 287, 295 (Pa. 1956).

105. It should be noted that a new trustee would be appointed under the doctrine of cy pres rather than by application of the familiar equitable maxim that a trust will not fail for want of a trustee, for here the trustee is not merely a formal manager but was chosen for its peculiar qualities and is an integral part of the trust scheme. There can be no doubt that Girard placed special confidence in the city, for he knew that he must "leave, necessarily, many details to the Mayor, Aldermen and citizens of Philadelphia and their successors. . ." Girard Will cl. XXI. As trustee, the city adds prestige, repute and dignity to the project. Through reports to the legislature and an audit by the city treasurer, the possibility of defalcation is minimized. These were all purposes Girard had in mind when he designated the city as trustee. Furthermore, city trusteeship was to serve to quicken the interest of citizens in their choice of government officials. "From the nature of my bequests and the benefit to result from them, I trust that my fellow citizens of Philadelphia, will observe and evince especial care and anxiety in selecting members for their city councils, and other agents." Ibid. Under these conditions, if the trustee cannot serve, there is a partial failure of the trust which is saved by $c y$ pres.

When a trustee of a charitable trust, chosen for its particular qualities, is unable to serve, the normal application of the doctrine of cy pres would be the appointment of a new trustee. However, this is so because usually there is no way of removing the named trustee's infirmity. He has either died, refused to serve or is incompetent for reasons unrelated to the trust itself. The Pennsylvania Supreme Court cites Vidal v. Mayor, 43 U.S. (2 How.) 126 (1844) for its statement that were the city unable to serve as trustee the remedy would be the appointment of a private trustee. In re Estate of Stephen Girard, supra note 104, at 295. The case is inapposite, however, because the hypothetical infirmity with which the court was dealing in Vidal was incurable. In the present Girard Estate case the infirmity may be cured by removing the racial restriction in the trust. In its application of $c y$ pres and choice of alternative remedies, the court should be guided by the supposed desires of the testator. 
infirmity. Whether or not the court would convert into holding its dictum concerning the remedy after the exhaustive arguments that would ensue on a remand from the United States Supreme Court (assuming that Court held for the petitioners on the constitutional issue), the gratuitous indication of the remedy presents more immediate problems. If under no view of the case would the Negro petitioners be admitted, the case as to them would be moot-as the Pennsylvania court could hardly have been unaware. Thus the Negroes could not have the decision reviewed in the United States Supreme Court either by certiorari or appeal. ${ }^{108}$

However, there are two other petitioners in the case. Both the City of Philadelphia and the Commonwealth of Pennsylvania intervened on the side of the original Negro petitioners. Although the city (as opposed to the Board of City Trusts) would not have standing in the Supreme Court since it has no legal interest in the trust, the Commonwealth has an interest both as remainderman ${ }^{107}$ and as parens patriae charged with the enforcement of charitable trusts. But if the appropriate remedy is to change trustees, the state would have no standing in its capacity as remainderman. This squarely raises the problem of whether the state has standing solely as parens patriae, an issue which helps to make this case a lawyer's dream (or nightmare). Among the several problems here is that the state appears on both sides of the case, through the Attorney General and the Board of City Trusts. The solution to this problem, happily, is belond the scope of this article.

\section{See note 16 supra.}

107. The will provided that if the city knowingly and willfully violated any of the testamentary conditions, the remainder was to go to the Commonwealth of Pennsylvania for the purposes of internal navigation, "excepting, however, the rents, issues and profits of my real estate in the City and County of Philadelphia which shall forever be reserved and applied to maintain the aforesaid college in the manner specified in the last paragraph of the XXIst clause of this will." Girard Will cl. XXIV. 